\title{
PREFERENSI KONSUMEN TERHADAP SAYURAN INDIJENES
}

\author{
W Nahraeni ${ }^{1}$, A Rahayu ${ }^{2}$, A. Yusdiarti ${ }^{1}$ \\ ${ }^{1}$ Staf Pengajar Jurusan Agribisnis, Fakultas Pertanian, Universitas Djuanda Bogor \\ ${ }^{2}$ Staf Pengajar Jurusan Agroteknologi, Fakultas Pertanian, Universitas Djuanda Bogor \\ Jalan Tol Ciawi No. 1 Kotak Pos 35 Bogor 16720 \\ ${ }^{a}$ Korespondensi: Wini Nahraeni. Telp: 08129682305; E-mail: winisivadevi@yahoo.com
}

\begin{abstract}
ABSTRAK
Penelitian ini bertujuan untuk mengukur preferensi konsumen terhadap lima komoditas sayuran indijenes daun di Kabupaten Bogor dan Sukabumi. Sayuran daun yang diamati adalah katuk, kenikir, poh-pohan, kemangi, dan reundeu. Lokasi penelitian untuk mendapatkan keanekaragaman jenis sayuran indijenes dilakukan di tiga kabupaten/kotamadya yaitu Bogor, Sukabumi dan Cianjur Provinsi Jawa Barat sedangkan lokasi penelitian untuk melihat preferensi konsumen dilakukan di Kabupaten Bogor, Sukabumi, dan Jakarta. Data diperoleh dari hasil wawancara dengan responden ibu rumah tangga sebanyak 50 orang konsumen. Hasil Penelitian menunjukan bahwa atribut yang paling penting dalam preferensi sayuran indijenes adalah rendahnya zat berbahaya, harga dan tingginya kandungan zat berkhasiat. Dari segi rasa, Sayuran yang paling disukai adalah kemangi, reundeu dan kenikir. Dari ketersediaan, yang paling baik kinerjanya adalah kemangi dan pohpohan. Sayuran yang ketersediannya jarang atau paling sulit didapatkan adalah kenikir. Hasil analisis Multiatribut Fishbeinn menunjukan bahwa sayuran daun yang paling disukai konsumen adalah kemangi, pohpohan dan katuk
\end{abstract}

Kata Kunci : Sayuran Indijenes, Preferensi Konsumen, Fishbeinn

\section{PENDAHULUAN}

Indonesia dikenal sebagai negara dengan keanekaragaman hayati terbesar di dunia, setelah Brazilia dan Madagaskar (Baihaki, 2003), termasuk diantaranya yang tergolong tanaman sayuran. Walaupun demikian, belum semua aksesi sayuran telah dimanfaatkan dan diproduksi secara komersial, sehingga disebut sebagai sayuran under utilized atau indigenous atau indijenes. Sayuran under-utilized umumnya merujuk kepada spesies yang memiliki potensi, tetapi belum dimanfaatkan secara penuh (Tontisirin, 2014). Sayuran indijenes (indigenous) adalah spesies sayuran asli pada daerah tertentu atau berasal dari wilayah atau ekosistem tertentu, termasuk spesies atau varietas introduksi yang sudah lama berevolusi dari wilayah geografis lain (Hidayat et al., 2006).

Menurut Direktorat Pengolahan dan Pemasaran Hasil Hortikultura (2017), pada tahun 2015 tingkat konsumsi sayuran penduduk Indonesia adalah sebesar 39,86kg/kapita/tahun, masih jauh di bawah standar yang ditetapkan oleh FAO, sebesar $73 \mathrm{~kg} / \mathrm{kapita} / \mathrm{tahun}$. Menurut WHO (2005), konsumsi buah dan sayur akan meningkat seiring dengan peningkatan pendapatan dan dengan urbanisasi. Permintaan sayuran indijenes, terutama di Provinsi Jawa Barat cenderung terus meningkat. Hal ini tampak dari dijualnya beberapa sayuran indijenes, seperti daun pakis, daun labu siam, kecipir, leunca, takokak dan katuk di gerai pasar swalayan besar di Bogor dan Sukabumi. Peningkatan perkembangan restoran khas 
Jawa Barat yang menyajikan aneka sayuran indijenes juga menunjukkan prospek yang baik. Selain itu peningkatan kesadaran masyarakat mengenai gaya hidup sehat, turut mendorong peningkatan konsumsi sayuran. Lebih lanjut konsumen hortikultura yang menuntut produk yang aman dan sehat dari rantai pasok yang dapat dipercaya (Sa'id, 2011), diharapkan akan mendorong kenaikan permintaan sayuran indijenes, karena sayuran indijines biasanya diproduksi secara organik. Di sisi lain upaya pengembangan sayuran indijenes perlu memperhatikan perilaku dan preferensi konsumen terhadap atribut kualitas sayuran indijines.

Penelitian ini bertujuan untuk mengukur preferensi konsumen terhadap lima komoditas sayuran indijenes daun di Kabupaten Bogor dan Sukabumi, sehingga diperoleh informasi mengenai atribut kualitas sayuran indijenes berdasarkan preferensi konsumen. Sayuran daun yang dianalisis adalah katuk, kenikir, poh-pohan, kemangi, dan reundeu.

\section{MATERI DAN METODE Penentuan Lokasi Penelitian}

Penelitian ini dimulai dengan penelitian eksploratif meliputi observasi lapangan dan kuesioner. Eksplorasi dilakukan di tiga kabupaten/kotamadya yaitu Bogor, Sukabumi dan Cianjur Provinsi Jawa Barat, untuk mendapatkan keanekaragaman jenis sayuran indijenes. Selanjutnya penelitian preferensi konsumen dilakukan di Kabupaten Bogor. Sukabumi, dan Jakarta. Penelitian dilaksanakan April - Nopember 2016.

\section{Jenis dan Sumber Data}

Data yang digunakan adalah data primer (primary data source) dan data sekunder (secondary data source) yang berasal dari lembaga terkait seperti BPS, Dinas Pertanian Provinsi Jawa Barat dan lainnya. Data primer diperoleh dari wawancara dengan responden ibu rumah tangga sebanyak 50 orang konsumen. Kuesioner yang disebarkan kepada konsumen berisi pertanyaan-pertanyaan tentang karakteristik responden, tingkat kepentingan responden terhadap atributatribut sayuran indijines, tingkat kepercayaan konsumen terhadap sayuran indijines. Karakteristik responden meliputi: umur, jumlah anggota keluarga, tingkat pendidikan, pengalaman, pekerjaan, pendapatan, dan pengeluaran setiap bulannya

Metode pengambilan sampel yang digunakan dalam penelitian ini adalah metode non probability sampling yaitu metode accidental. Metode ini merupakan suatu cara pengambilan sampel yang dilakukan kepada konsumen yang bersedia mengisi kuesioner yang telah disiapkan, dengan kriteria yaitu orang telah pernah membeli sayuran indijenes dan memiliki keputusan sendiri dalam melakukan pembelian sayuran indijenes. Metode pengumpulan data yang dilakukan adalah metode survey dengan menggunakan kuesioner sebagai instrumen penelitian.

\section{Metode Analisis Data}

\section{Uji Validitas dan Realibilitas dilakukan dengan uji korelasi Pearson.}

\section{Analisis Preferensi Konsumen}

Untuk mengetahui perilaku konsumen dalam melakukan pembelian sayuran indijenes, kepada konsumen diminta untuk menyusun skala urutan atribut kualitas yang dijadikan dasar konsumen dalam melakukan pembelian. Untuk menentukan ranking yang mempengaruhi pertimbangan konsumen dalam membeli sayuran indijenes digunakan tabel ranking kemudian dianalisis secara deskriptif.

\section{Analisis Multi Atribut Fishbein}

Sumarwan (2004) menyatakan bahwa ntuk melihat sayuran indijenes yang 
memiliki skor sikap paling tinggi digunakan alat analisis sikap Fishbein. Analisis ini mengemukakan bahwa sikap terhadap objek tertentu didasarkan pada perangkat kepercayaan dan diberi nilai bobot sebagai nilai evaluasi terhadap atribut tersebut. Rumus multi atribut Fishbein:

Keterangan :

$$
A_{0}={ }_{i=1}^{n} b_{i} e_{i}
$$

$\mathrm{Ao}=$ Sikap konsumen terhadap sayuran indijenes

bi= Tingkat Keyakinan konsumen bahwa sayuran-sayuran indijenes memiliki atribut tertentu (atribut ke-i)

$\mathrm{ei}=$ dimensi evaluatif konsumen terhadap variabel ke-i yang dimiliki sayuran indijenes

$\mathrm{n}=$ Jumlah atribut yang dimiliki buah sayuran indijenes

Untuk menjawab tujuan penelitian ini digunakan metode 'sikap-kepentingan dan kepercayaan konsumen' terhadap atribut-atribut sayuran daun indijenes. Sikap konsumen terhadap sebuah produk ditentukan oleh dua hal yaitu (komponen bi) dan evaluasi pentingnya atribut dari produk tersebut (komponen ei). Atribut yang diseleksi dalam penelitian ini yaitu rasa, ketersediaan, masa ketersediaan, kemudahan mengolah, jenis olahan, harga, kemudahan dikunyah, kandungan zat berkhasiat, warna, ukuran, kandungan zat berbahaya, dan daya simpan. Variabel kekuatan kepercayaan (bi) dan kekuatan kepentingan (ei) diukur dengan semantic-diferential-scale dengan skor 1-5 yang menunjukkan skala sangat tidak penting (1) hingga sangat penting (5) untuk mengukur kepentingan. Metode analisis yang digunakan adalah statistika deskriptif dan Model Multi Atribut Fishbein dan Matriks IPA (Importance and Performance Analysis).

\section{HASIL DAN PEMBAHASAN}

\section{Karakteristik Responden}

Responden konsumen dalam penelitian ini berjumlah 50 orang, mereka berasal dari Kabupaten Bogor dan Jakarta.

Tabel 1. Karakteristik responden sayuran indijenes, 2016

\begin{tabular}{|c|c|c|c|}
\hline Variabel & Karakteristik Responden & $\begin{array}{c}\text { Frekuensi } \\
\text { (orang) }\end{array}$ & Persentase $(\%)$ \\
\hline \multirow[t]{3}{*}{ Jenis Kelamin } & Pria & 0 & 0 \\
\hline & Wanita & 50 & 100 \\
\hline & Jumlah & 50 & 100 \\
\hline \multirow[t]{8}{*}{ Usia (tahun) } & $<25$ & 0 & 0 \\
\hline & $25-30$ & 4 & 8 \\
\hline & $31-35$ & 5 & 10 \\
\hline & $36-40$ & 12 & 24 \\
\hline & $41-45$ & 8 & 16 \\
\hline & $46-50$ & 10 & 20 \\
\hline & $>50$ & 11 & 22 \\
\hline & Jumlah & 50 & 100 \\
\hline \multirow[t]{4}{*}{ Pendidikan } & SD & 6 & 12 \\
\hline & SLP & 4 & 8 \\
\hline & SLA & 11 & 22 \\
\hline & $\mathrm{S} 1$ & 6 & 12 \\
\hline
\end{tabular}




\begin{tabular}{|c|c|c|c|}
\hline Variabel & Karakteristik Responden & $\begin{array}{c}\text { Frekuensi } \\
\text { (orang) }\end{array}$ & Persentase $(\%)$ \\
\hline \multirow{7}{*}{ Pekerjaan } & $\mathrm{S} 2$ & 23 & 46 \\
\hline & Jumlah & 50 & 100 \\
\hline & Ibu Rumah Tangga & 15 & 30 \\
\hline & Pegawai Swasta & 21 & 42 \\
\hline & Pegawai negeri & 8 & 16 \\
\hline & Wirausaha & 6 & 12 \\
\hline & Jumlah & 50 & 100 \\
\hline \multirow[t]{6}{*}{ Pendapatan (Rp) } & $<1.500 .000$ & 8 & 16 \\
\hline & $1.500 .000-3000.000$ & 19 & 38 \\
\hline & $3.000 .000-5.000 .000$ & 12 & 24 \\
\hline & $5.000 .000-7.500 .000$ & 7 & 14 \\
\hline & $>7.500 .000$ & 4 & 8 \\
\hline & Jumlah & 50 & 100 \\
\hline \multirow{5}{*}{$\begin{array}{l}\text { Jumlah Tanggungan } \\
\text { Keluarga }\end{array}$} & $<1$ & 6 & 12 \\
\hline & $1-2$ & 21 & 42 \\
\hline & 3- 4 & 20 & 40 \\
\hline & $>4$ & 3 & 6 \\
\hline & Jumlah & 50 & 100 \\
\hline
\end{tabular}

Hasil analisis pada Tabel 1 menunjukkan bahwa semua responden adalah wanita (100\%). Angka ini menunjukkan bahwa pengambilan keputusan pembelian sayuran indijenes lebih banyak dilakukan oleh wanita. Struktur usia responden sebagian besar didominasi oleh ibu-ibu rumah tangga yang berusia lebih dari 36 tahun $(82 \%)$. Tingkat pendidikan responden dapat dikatakan cukup baik, hampir $56 \%$ berpendidikan sarjana dan pasca sarjana, SLA (22\%), SLP (8\%), dan konsumen yang berpendidikan SD sebanyak $12 \%$. Berdasarkan jenis pekerjaan, sebagian besar responden cenderung mempunyai pekerjaan yang cukup baik, dengan jenis pekerjaan pegawai swasta (46\%), ibu rumah tangga (30\%), PNS (16\%) dan sisanya berwirausaha $(12 \%)$.
Ditinjau dari tingkat pendapatan keluarga, sebagian besar responden berada pada kisaran pendapatan $\mathrm{Rp} 1.500 .000$ Rp 3.000.000 (38\%), diikuti oleh responden berpendapatan $\mathrm{Rp} 3.000 .000$ - 5.000.000 $(24 \%)$. Sebagian besar responden rata-rata mempunyai tanggungan keluarga 1-2 orang (42\%) dan $40 \%$ mempunyai tanggungan keluara antara 3- 4 orang

\section{Analisis Tingkat Kepentingan Atribut}

Data untuk tingkat kepentingan dalam penelitian ini diperoleh dari wawancara dengan menggunakan kuesioner. Data ordinal menggunakan skala Likert dari 1-5. Responden diminta untuk memilih atribut dari nilai 1 sangat tidak penting, nilai 2 tidak penting, nilai 3 untuk biasa/netral, nilai 4 untuk penting, dan nilai 5 sangat penting. Hasil wawancara untuk berbagai sayuran indijenes ditunjukkan pada Tabel 2. 
Tabel 2. Evaluasi konsumen (peringkat kepentingan) atribut sayuran indijenes, 2016

\begin{tabular}{|c|c|c|c|c|c|c|c|}
\hline No & Atribut & Katuk & Kenikir & Pohpohan & Kemangi & Reundeu & Rataan \\
\hline 1 & Rasa & 4.24 & 3.70 & 4.17 & 4.02 & 3.23 & 3.87 \\
\hline 2 & Ketersediaan & 3.63 & 3.30 & 4.04 & 3.87 & 3.49 & 3.67 \\
\hline 3 & $\begin{array}{l}\text { Masa } \\
\text { Ketersediaan }\end{array}$ & 3.57 & 3.20 & 3.46 & 3.54 & 3.79 & 3.51 \\
\hline 4 & $\begin{array}{l}\text { Kemudahan } \\
\text { Mengolah }\end{array}$ & 4.00 & 2.83 & 3.65 & 2.59 & 2.79 & 3.17 \\
\hline 5 & Jenis Olahan & 3.63 & 2.85 & 2.91 & 2.72 & 2.88 & 3.00 \\
\hline 6 & Harga & 3.96 & 3.78 & 4.07 & 3.96 & 3.88 & 3.93 \\
\hline 7 & $\begin{array}{l}\text { Kemudahan } \\
\text { Dikunyah }\end{array}$ & 4.15 & 4.07 & 4.00 & 4.26 & 3.84 & 4.06 \\
\hline 8 & $\begin{array}{l}\text { Kandungan Zat } \\
\text { Berkhasiat }\end{array}$ & 4.04 & 4.43 & 3.87 & 4.28 & 4.21 & 4.17 \\
\hline 9 & Warna & 2.98 & 2.28 & 3.26 & 2.43 & 3.23 & 2.84 \\
\hline 10 & Ukuran & 3.65 & 3.46 & 3.78 & 3.76 & 3.77 & 3.68 \\
\hline 11 & $\begin{array}{l}\text { Kandungan Zat } \\
\text { Berbahaya }\end{array}$ & 3.83 & 3.63 & 3.89 & 3.93 & 3.79 & 3.81 \\
\hline 12 & Daya Simpan & 4.33 & 4.30 & 4.22 & 3.96 & 3.81 & 4.12 \\
\hline
\end{tabular}

Atribut yang paling dipentingkan oleh konsumen berbeda beda untuk tiap komoditas. Untuk katuk dan pohpohan konsumen lebih mementingkan keamanan dari kandungan zat berbahaya, daya simpan, dan kemudahan dikunyah, sedangkan atribut yang kurang dipentingkan aadalah warna dan jenis olahan. Pada Sayuran kenikir,kemangi dan reundeu, konsumen lebih mementingkan kandungan zat berkhasiat, sedangkan pada pohpohan dan katuk daya simpan menjadi pertimbangan utama dalam membeli Sayuran tersebut.

Tabel 3. Skor tingkat kepercayaan responden terhadap kinerja sayuran indijenes

\begin{tabular}{|c|c|c|c|c|c|c|c|c|c|c|c|c|c|}
\hline $\begin{array}{l}\text { Jenis } \\
\text { Sayuran }\end{array}$ & 1 & 2 & 3 & 4 & 5 & 6 & 7 & 8 & 9 & 10 & 11 & 12 & $\begin{array}{l}\text { Rata } \\
\text {-rata }\end{array}$ \\
\hline Katuk & $\begin{array}{l}2.6 \\
2\end{array}$ & $\begin{array}{l}1.9 \\
1\end{array}$ & $\begin{array}{l}3.7 \\
4\end{array}$ & $\begin{array}{l}4.2 \\
6\end{array}$ & $\begin{array}{l}1.8 \\
1\end{array}$ & $\begin{array}{l}4.3 \\
4\end{array}$ & $\begin{array}{l}3.4 \\
3\end{array}$ & $\begin{array}{l}4.1 \\
9\end{array}$ & $\begin{array}{l}3.2 \\
6\end{array}$ & $\begin{array}{l}4.1 \\
5\end{array}$ & 4.4 & 1.6 & 3.31 \\
\hline Kemangi & $\begin{array}{l}4.1 \\
1\end{array}$ & $\begin{array}{l}3.2 \\
4\end{array}$ & 4.2 & $\begin{array}{l}3.9 \\
3\end{array}$ & $\begin{array}{l}4.1 \\
5\end{array}$ & $\begin{array}{l}4.2 \\
8\end{array}$ & $\begin{array}{l}4.4 \\
8\end{array}$ & $\begin{array}{l}4.3 \\
3\end{array}$ & $\begin{array}{l}3.9 \\
8\end{array}$ & 4 & $\begin{array}{l}4.5 \\
2\end{array}$ & $\begin{array}{l}2.5 \\
7\end{array}$ & 3.98 \\
\hline $\begin{array}{l}\text { Poh- } \\
\text { Pohan }\end{array}$ & $\begin{array}{l}2,2 \\
7\end{array}$ & 3.7 & 3 & $\begin{array}{l}4.1 \\
6\end{array}$ & $\begin{array}{l}2.6 \\
6\end{array}$ & $\begin{array}{l}4.5 \\
5\end{array}$ & $\begin{array}{l}3.3 \\
9\end{array}$ & 4.3 & $\begin{array}{l}2.5 \\
9\end{array}$ & 4.3 & $\begin{array}{l}4.5 \\
7\end{array}$ & $\begin{array}{l}1.8 \\
2\end{array}$ & 3.55 \\
\hline Reundeu & $\begin{array}{l}3,0 \\
3\end{array}$ & $\begin{array}{l}2.0 \\
8\end{array}$ & 2 & $\begin{array}{l}4.0 \\
8\end{array}$ & $\begin{array}{l}1.9 \\
7\end{array}$ & $\begin{array}{l}4.3 \\
9\end{array}$ & $\begin{array}{l}3.5 \\
8\end{array}$ & $\begin{array}{l}4.2 \\
6\end{array}$ & $\begin{array}{l}2.7 \\
4\end{array}$ & $\begin{array}{l}3.7 \\
9\end{array}$ & $\begin{array}{l}4.3 \\
4\end{array}$ & $\begin{array}{l}1.8 \\
7\end{array}$ & 3.19 \\
\hline Kenikir & 2.6 & $\begin{array}{l}1.6 \\
9\end{array}$ & $\begin{array}{l}2.6 \\
4\end{array}$ & 4.2 & 1.8 & $\begin{array}{l}4.5 \\
1\end{array}$ & $\begin{array}{l}3.3 \\
3\end{array}$ & $\begin{array}{l}4.2 \\
2\end{array}$ & 2.7 & 3.8 & $\begin{array}{l}4.3 \\
7\end{array}$ & $\begin{array}{l}1.7 \\
2\end{array}$ & 3.13 \\
\hline Rata-rata & $\begin{array}{l}3.1 \\
1 \\
\end{array}$ & $\begin{array}{l}2.5 \\
2 \\
\end{array}$ & $\begin{array}{l}3.1 \\
2 \\
\end{array}$ & $\begin{array}{l}4.1 \\
3 \\
\end{array}$ & $\begin{array}{l}2.4 \\
8 \\
\end{array}$ & $\begin{array}{l}4.4 \\
1 \\
\end{array}$ & $\begin{array}{l}3.6 \\
4 \\
\end{array}$ & $\begin{array}{l}4.2 \\
6 \\
\end{array}$ & $\begin{array}{l}3.0 \\
5 \\
\end{array}$ & $\begin{array}{l}4.0 \\
1 \\
\end{array}$ & $\begin{array}{l}4.4 \\
4 \\
\end{array}$ & $\begin{array}{l}1.9 \\
2 \\
\end{array}$ & 3.43 \\
\hline Peringkat & 8 & 10 & 7 & 4 & 11 & 2 & 6 & 3 & 9 & 5 & 1 & 12 & \\
\hline
\end{tabular}


Keterangan :

1 : rasa, 2 : ketersediaan, 3 : masa ketersediaan, 4 : kemudahan mengolah, $5:$ jenis olahan, $6:$ harga, $7:$ kemudahan dikunyah, $8:$ Kandungan Zat Berkhasiat, $9:$ warna, $10:$ ukuran, $11:$ kandungan zat berbahaya, $12:$ daya simpan

Dari segi rasa, Sayuran yang paling disukai adalah kemangi, diikuti oleh reundeu dan kenikir. Dari ketersediaan, yang paling baik kinerjanya adalah kemangi, lalu pohpohan. Sayuran yang ketersediannya jarang atau paling sulit didapatkan adalah kenikir (1,69), Untuk semua Sayuran daun, yang dianggap kinerjanya baik adalah keamanan dari kandungan zat berbahaya, harga, kandungan zat berhasiat, sedangkan atribut daya simpan, jenis olahan dan warna. Berdasarkan hasil penelitian dengan menggunakan analisis Multiatribut Fishbein, diperoleh hasil bahwa sayuran indijenes yang paling disukai oleh responden berdasarkan penilaian pembobotan terhadap atribut adalah kemangi, lalu pohpohan. Katuk reundeu dan kenikir (Tabel 3).

Daun kemangi mengandung senyawa luteolin dan apigenin dalam jumlah tinggi dibandingkan sayuran indijenes lainnya (Batari, 2007). Senyawa luteolin memiliki peran yang penting dalam tubuh manusia sebagai antioksidan, penangkap radikal bebas, zat pencegah terhadap peradangan, promotor dalam metabolisme karbohidrat, dan sebagai pengatur sistem imun. Berdasarkan karakteristik-karakteristik tersebut, luteolin juga dipercaya dapat memainkan peran yang penting dalam pencegahan terhadap kanker. Senyawa apigenin memiliki kemampuan antara lain sebagai zat anti peradangan, antibakteri, dan untuk mengatasi permasalahan lambung (Cadenas dan Packer dalam Batari, 2007).

\section{Importance and Performance Analysis (IPA)}

Nilai-nilai pada Tabel 2 dan 3 kemudian diplotkan ke dalam Tabel 5 yang terdiri atas empat kuadran. Kuadran I merupakan kuadran dengan prioritas utama, kuadran II pertahankan prestasi, kuadran III prioritas rendah, dan kuadran IV berlebihan. Hasil Analisis IPA bisa dilihat pada Tabel 5.

Secara keseluruhan, dapat dilihat pada Tabel 4 bahwa atribut yang secara dominan ada di kuadran I adalah daya simpan (terdapat di seluruh sayuran), rasa (terdapat di 3 sayuran) dan ketersediaan (terdapat di 1 sayuran). Atribut yang dominan ada di kuadran II adalah kandugan zat berkhasiat (seluruh sayuran), kandungan zat berbahaya ( kecuali katuk), kemudahan dikunyah (4 sayuran. Kecuali pohpohan), dan harga (seluruh sayuran). Atribut yang mayoritas ada di Kuadran III adalah jenis olahan (4 sayuran), dan warna (4 sayuran). Kuadran IV didominasi oleh atribut kemudahan mengolah (3 sayuran).

Tabel 4. Hasil important and performance matrix responden sayuran indijenes

\begin{tabular}{lcccc}
\hline Jenis Sayuran & Kuadran I & Kuadran II & Kuadran III & Kuadran IV \\
\hline Katuk & $(1),(12)$ & $(4),(6),(7),(8),(1)$ & $(2),(5),(9)$ & $(3),(10)$ \\
Kenikir & $(1),(12)$ & $(6),(7),(8),(11)$ & $(2),(3),(5),(9)$ & $(4)$ \\
Poh-pohan & $(1),(7),(12)$ & $(2),(6),(8),(11)$ & $(3),(5),(9)$ & $(4),(10)$ \\
Rendeu & $(3),(12)$ & $(6),(7),(8),(10),(11)$ & $(1),(2),(5),(9)$ & $(4)$ \\
Kemangi & $(2),(12)$ & $(1),(6),(7),(8),(10),(11)$ & $(4)$ & $(3),(5),(9)$ \\
\hline
\end{tabular}


Keterangan:

1 : rasa, 2 : ketersediaan, 3 : masa ketersediaan, $4:$ kemudahan mengolah, $5:$ jenis olahan, 6 : harga, 7 : kemudahan dikunyah, 8 : Kandungan Zat Berkhasiat, 9 : warna, 10 : ukuran, 11 : kandungan zat berbahaya, 12 : daya simpan

Secara keseluruhan, dapat dilihat pada Tabel 4 bahwa atribut yang secara dominan ada di kuadran I adalah daya simpan (terdapat di seluruh sayuran), rasa (terdapat di 3 sayuran) dan ketersediaan (terdapat di 1 sayuran). Atribut yang dominan ada di kuadran II adalah kandugan zat berkhasiat (seluruh sayuran), kandungan zat berbahaya ( kecuali katuk), kemudahan dikunyah (4 sayuran. Kecuali pohpohan), dan harga (seluruh sayuran). Atribut yang mayoritas ada di Kuadran III adalah jenis olahan (4 sayuran), dan warna (4 sayuran). Kuadran IV didominasi oleh atribut kemudahan mengolah (3 sayuran).

Artinya untuk seluruh sayuran daun yang dianalisis, atribut yang harus dipernai kinerjanya adalah daya simpan. Atribut lainnya adalah rasa ( katuk. Pohpohan, dan kenikir), ketersediaan (kemangi) dan masa ketersediaan (reundeu).

\section{KESIMPULAN DAN IMPLIKASI KEBIJAKAN}

Atribut yang paling penting adalah rendahnya zat berbahaya, harga dan tingginya kandungan zat berkhasiat. Sementara itu tanaman sayuran kinerja terbaik adalah kemangi, kecipir dan leunca. Berdasarkan hasil analisis Multiatribut Fishbein, sayuran daun yang paling disukai konsumen adalah kemangi, pohpohan dan katuk

Untuk tahap berikutnya analisis preferensi konsumen sebaiknya dilakukan bersamaan dengan uji organoleptik pada responden dari suku Sunda (Jawa Barat)

\section{UCAPAN TERIMA KASIH}

Ucapan terima kasih diucapkan
kepada Direktur Riset dan Pengabdian
Masyarakat Direktorat Jendeeral Penguatan Riset dan Pengembangan Kementerian Riset, Teknologi, dan Pendidikan Tinggi yang telah membiayai penelitian ini

\section{DAFTAR PUSTAKA}

Adiyoga, W., M. Ameriana, dan T.A. Soetiarso. 2008. Segmentasi pasar dan Pemetaan Persepsi Atribut Produk Beberapa Jenis Sayuran Minor (Under-Utilized). Jurnal Hortikultura 18 (4):466-476.2008.

Baihaki, A. 2003. Aspek sosial ekonomi dalam pemanfaatan dan pelestarian keanekaragaman hayati Jawa Barat. J. Ekologi dan Biodiversitas Tropika 2(2):54-60.

Hidayat, IM, Kirana R, Gaswanto R, Kusmana. 2006. Petunjuk Teknis Budidaya dan Produksi Beberapa Sayuran Indigenous. Balitsa. Puslitbanghorti. Balitbangtan.

Keatinge, J.D.H.; Yang, R.-Y.; Hughes, J.d'A.; Easdown, W.J.; Holmer, R. The importance of vegetables in ensuring both food and nutritional security in attainment of the Millennium Development Goals. Food Sci. 2011, 3, 491-501.

Keatinge JDH, Holmer RJ, Ebert AW, Hughes Jd'A. 2014. Less visible but yet vital for human health: Nutrientdense indigenous vegetables and their need for urgent promotion in balanced diets. In Patrick Durst and Nomindelger Bayasgalanbat. (Editor). Promotion of Underutilized Indigenous Food Resources for Food Security and Nutrition in Asia and the Pacific. Food and 
Agriculture Organization of the United Nations Regional Office for Asia and the Pacific. Bangkok.

Kementrian Pertanian. 2010. Konsumsi

sayur masyarakat Indonesia di bawah rekomendasi FAO.

Www.agro.agroprima.com [18 Mei 2011]

Kementrian Pertanian. 2012. Pengembangan Kawasan Rumah Lestari. Kementrian Pertanian dan SIKIB. Jakarta

Kotler P. 2000. Manajemen Pemasaran Edisi Milenium Jilid 1. Penerbit Erlangga. Jakarta.

Sa'id, EG. 2011. Peningkatan Nilai Tambah untuk Mendukung Daya Saing Produk Hortikultura Indonesia di Pasar Global. Prosiding Seminar Nasional Perhimpunan Hortikultura Indonesia. Balitsa Lembang 23-24 Nopember 2011.

Soetiarso TA. 2010. Preferensi Konsumen terhadap Atribut Kualitas Empat Jenis Sayuran Minor. J. Hort. 20(4):398407.

Somantri. 2006. Pentingnya Melestraikan Syuran Indigenous (Indijenes).Makalah disampaikan pada pelatihan " Promosi Pemanfaatan Sayuran Indigenous untuk Peningkatan Nutrisi Keluarga melalui Kebun Pekarangan. Jakarta 17-19 April 2006. $6 \mathrm{Hlm}$.

Sumarwan U, Jauzi A, Mulyana A, Karno BN, Mawrdi P.K., Nugroho W. 2013. Riset Pemasaran dan Konsumen Seri 1 Cetakan kedua. PT Penerbit IPB Press. Bogor.

Tontisirin, K. 2014 . Promotion of underutilized indigenous food resources for food security and nutrition in Asia and the Pacific. In Patrick Durst and Nomindelger Bayasgalanbat. (Editor). Promotion of Underutilized Indigenous Food Resources for Food Security and Nutrition in Asia and the Pacific. Food and Agriculture Organization of the United Nations Regional Office for Asia and the Pacific. Bangkok. 